\title{
2-Methoxy-4-vinylphenol Attenuates Migration of Human Pancreatic Cancer Cells via Blockade of FAK and AKT Signaling
}

\author{
DA-HYE KIM ${ }^{1}$, SONG-I HAN ${ }^{2}$, BORAM GO ${ }^{3}$, UI HYEON OH ${ }^{1}$, CHANG-SOOK KIM ${ }^{1}$, \\ YONG-HWAN JUNG ${ }^{3}$, JUNGWHOI LEE ${ }^{2}$ and JAE-HOON KIM ${ }^{1,2}$ \\ ${ }^{1}$ Department of Biotechnology, College of Applied Life Science, Jeju National University, Jeju, Republic of Korea; \\ ${ }^{2}$ Subtropical/Tropical Organism Gene Bank, Jeju National University, Jeju, Republic of Korea; \\ ${ }^{3}$ Jeju Biodiversity Research Institute, Jeju Technopark, Jeju, Republic of Korea
}

\begin{abstract}
Background/Aim: No effective therapeutics have yet been developed for pancreatic cancer. 2-Methoxy-4-vinyl phenol (2M4VP), a member of the class of phenols, has been demonstrated to have anti-inflammatory properties and cause cell cycle arrest making it an attractive candidate drug for the treatment of pancreatic cancer. Materials and Methods: The effects of 2M4VP were examined in Panc-1 and SNU-213 human pancreatic cancer cells. Results: 2M4VP had anticancer effects on pancreatic cancer cell lines, Panc-1 and SNU-213.2M4VP reduced the viability of Panc-1 cells by inhibiting the expression of the cell nuclear antigen (PCNA) protein. 2M4VP also suppressed the migratory activity of both cell lines. In addition, treatment with 2M4VP effectively decreased the phosphorylation of Focal Adhesion Kinase (FAK) and AKT. Conclusion: 2M4VP might be used as a pancreatic cancer treatment supplement.
\end{abstract}

Pancreatic cancer has a five-year survival rate of less than $5 \%$ (1-3). The main characteristics of pancreatic cancer are the early systemic metastasis and local tumor progression (46 ). The unique migratory activity of pancreatic cancer cells makes early diagnosis and treatment very difficult, and increases the mortality rate of pancreatic cancer patients $(7$, 8). Recently, it has been reported that gemcitabine, a drug

Correspondence to: Jae Hoon Kim, Ph.D., Department of Biotechnology, College of Applied Life Science, Jeju National University,102 Jejudaehak-ro, Jeju, 63608, Republic of Korea. Tel: +82 647563351, Fax: +82 647238273, e-mail: kimjh@jejunu.ac.kr; Jungwhoi Lee, Subtropical/Tropical Organism Gene Bank, Jeju National University, Jeju, Republic of Korea. Tel: +82 647298556, e-mail:sdjd1108@kaist.ac.kr

Key Words: 2-methoxy-4-vinylphenol, cell proliferation, cell migration, hepatocyte growth factor. used in current clinical trials, may cause metastasis at low dose in pancreatic cancers (9). Resistance to currently available anticancer drugs also makes this disease more difficult to treat $(10,11)$. In addition, a hepatocyte growth factor (HGF) has been noted for its role in pancreatic cancer and has been related with poor prognosis (12-14). Therefore, it is necessary to study the molecules that regulate the HGF pathway in pancreatic cancer cells.

Buckwheat is a dicotyledonous plant common in East Asian countries and contains various functional substances such as rutin, isovitexin, quercetin, which have been reported to have antioxidant, anti-inflammatory, and anti-cancer properties (15-19). In particular, buckwheat contains buckwheat flavor compounds, such as 2,5-dimethyl-4hydroxy-3(2H)-furanone, (E-)-2,4-decadienal, and 2Methoxy-4- vinylpenol (2M4VP). Especially, 2M4VP is used as a fragrance and is also found in apples and peanuts. 2M4VP is also known to induce cell cycle arrest by blocking the hyper-phosphorylation of retinoblastoma protein in benzopyrene-treated NIH3T3 cells and to have an antiinflammatory effect by inhibiting mitogen-activated protein kinase (MAPK) activation $(20,21)$. In this study, we investigated the anticancer effects of $2 \mathrm{M} 4 \mathrm{VP}$ in pancreatic cancer cell lines.

\section{Materials and Methods}

Cell culture and reagents. We obtained 293T, Panc-1, and SNU-213 cells from the Korean Cell Line Bank (Seoul, Repubic of Korea). The 293T and Panc-1 cells were maintained in DMEM supplemented with $10 \%$ fetal bovine serum (Gibco-BRL, Gaithersburg, MD, USA), $100 \mathrm{U} / \mathrm{ml}$ penicillin and $100 \mu \mathrm{g} / \mathrm{ml}$ streptomycin (Invitrogen, Carlsbad, CA, USA) at $37^{\circ} \mathrm{C}$ and $5 \% \mathrm{CO}_{2}$. SNU-213 cells were maintained in RPMI-1640 supplemented with $10 \%$ fetal bovine serum (Gibco-BRL), $100 \mathrm{U} / \mathrm{ml}$ penicillin and $100 \mu \mathrm{g} / \mathrm{ml}$ streptomycin (Invitrogen) at $37^{\circ} \mathrm{C}$ and $5 \% \mathrm{CO}_{2}$. The $2 \mathrm{M} 4 \mathrm{VP}$ and HGF were purchased from Sigma-Aldrich (St. Louis, MO, USA). 
Cell viability assay. Cell viability was measured using the WST-1(2(4-iodophenyl)-3-(4-nitrophenyl)-5-(2, 4- disulfophenyl)-2Htetrazolium) assay (Boechringer Mannheim, Mannheim, Germany). Cells were seeded at a density of $2.5 \times 104$ per well in 24 -well plates. After incubation for $24 \mathrm{~h}$, they were treated with $2 \mathrm{M} 4 \mathrm{VP}$ for $72 \mathrm{~h}$ at $37^{\circ} \mathrm{C}$. Then, WST- 1 solution was added to the cells and incubated for $15 \mathrm{~min}$ at room temperature. The absorbance was measured at $450 \mathrm{~nm}$ using a microplate reader.

Flow cytometry analysis. For apoptosis analysis, Panc-1 and 293T cells were seeded in 6-well plates. After $24 \mathrm{~h}$, they were treated with 2M4VP for $72 \mathrm{~h}$. Cells were then collected and incubated with Annexin V-FITC and PI (FITC Annexin V apoptosis detection kit, BD Pharmigen, San Diego, CA, USA). The apoptotic cells were detected by flow cytometry (LSRFortessa, BD Pharmigen).

Cell migration assay. The filter was pre-coated with $1 \mu \mathrm{g} / \mu \mathrm{l}$ fibronectin (Sigma-Aldrich, St. Louis, MO, USA), and then $500 \mu \mathrm{l}$ RPMI were added to the lower chamber. The suspended cells in the upper chambers were treated with $\mathrm{HGF}$ for $30 \mathrm{~min}$ and then with $2 \mathrm{M} 4 \mathrm{VP}$ for $6 \mathrm{~h}$ at $37^{\circ} \mathrm{C}$ in serum-free medium. Then, cells were fixed using 4\% paraformaldehyde (Biosesang, Seongnam, Republic of Korea) and stained using $0.1 \%$ crystal violet solution. Finally, the solution was eluted with $10 \%$ acetic acid and absorbance was measured at $560 \mathrm{~nm}$ using a microplate reader.

Western blot assay. Cells were lysed in M-PER lysis buffer (Thermo science, Bonn, Germany) containing a protease inhibitor cocktail (Roche), $2 \mathrm{mM}$ sodium vanadate, $30 \mathrm{mM}$ sodium pyrophosphate, and $100 \mathrm{mM}$ sodium fluoride. After total protein quantification, proteins were separated by $10 \%$ SDS-PAGE (sodium dodecyl sulfatepolyacrylamide gel electrophoresis) and transferred to nitrocellulose membranes (Amersham Bioscience, Little Chalfont, Buckinghamshire, UK). Membranes were blocked with 5\% skim milk in TBST followed by incubation overnight at $4^{\circ} \mathrm{C}$ with primary antibodies, such as phospho-FAK (Tyr397), phospho AKT (Ser473), proliferating cell nuclear antigen (PCNA), and GAPDH (Cell signaling technology, Beverly, MA, USA), that were diluted 1:1000 in TBST. Membranes were then washed four times with TBST and incubated for $1 \mathrm{~h}$ with secondary antibodies (Merck Millipore, Germany) that were diluted 1:4000 in TBST. Membranes were then washed with TBST and the protein bands were detected by the ECL kit (Biosesang).

Statistical analysis. Error bars represent \pm SEM. Statistical analysis was performed using one-way ANOVA, two-way ANOVA, and student's $t$-test (SPSS, Chicago, IL, USA). $p<0.05$ was considered to indicate significant differences.

\section{Results}

2-Methoxy-4-vinyl phenol inhibited the proliferation of Panc1 cells. WST-1 assay was used to analyze the effect of different concentrations of 2M4VP on the proliferation of Panc-1 and SNU-213 cells. Panc-1 cells showed a significant $(p<0.001)$ decrease in viability after treatment with $2 \mathrm{M} 4 \mathrm{VP}$. In contrast, SNU-213 cell proliferation was not statistically significantly affected by 2M4VP. Moreover, treatment with $100 \mu \mathrm{M} 2 \mathrm{M} 4 \mathrm{VP}$ did not affect the viability of control 293T cells, indicating that $2 \mathrm{M} 4 \mathrm{VP}$ at a $100 \mu \mathrm{M}$ concentration was not cytotoxic (Figure
1A). Cells were treated with $2 \mathrm{M} 4 \mathrm{VP}$ and analyzed by flow cytometry to determine whether the reduction in viability of Panc-1 cells was due to apoptosis or to the inhibition of proliferation. Figure 1B shows that apoptosis did not occur in 2M4VP-treated Panc-1 cells and control 293T cells. Next, to investigate the effect of $2 \mathrm{M} 4 \mathrm{VP}$ on cell proliferation, the expression of PCNA was examined. PCNA was downregulated in Panc-1 cells after treatment with 2M4VP, but no significant changes were observed in SNU-213 and control cells (Figure 1C). These results showed that $2 \mathrm{M} 4 \mathrm{VP}$ inhibited proliferation of Panc-1 pancreatic cancer cells.

2M4VP inhibited metastasis of Panc-1 and SNU-213 cells by regulating $p-F A K$ and $p$-AKT. Panc- 1 and SNU-213 cells were treated with 0,10 , or $100 \mu \mathrm{M}$ of $2 \mathrm{M} 4 \mathrm{VP}$ for $6 \mathrm{~h}$ and analyzed using a transwell assay. Panc- 1 cell migration was reduced by about $15 \%$ after treatment for $6 \mathrm{~h}$ with $10 \mu \mathrm{M}$ 2M4VP (Figure 2A). In SNU-213 cells, 2M4VP inhibited migration by about $9 \%$ at a concentration of $10 \mu \mathrm{M}$ and about $17 \%$ at a concentration of $100 \mu \mathrm{M}$ (Figure 2B). These results suggest that $2 \mathrm{M} 4 \mathrm{VP}$ inhibits metastasis of pancreatic cancer cells and is more effective in Panc-1 than in SNU213 cells. To identify the mechanism of this inhibition, cells were treated with $2 \mathrm{M} 4 \mathrm{VP}(0,10,100 \mu \mathrm{M})$ for $24 \mathrm{~h}$ and analyzed for the phosphorylation levels of FAK (Tyr 397) and AKT (ser473) (Figure 3). p-FAK and p-AKT levels were reduced following treatment of Panc-1 cells with 2M4VP. However, p-FAK and p-AKT levels did not change in 2M4VP-treated control cells.

2M4VP inhibited the hepatocyte growth factor-induced metastasis of Panc-1 cells. Hepatocyte growth factor (HGF) is known to induce metastasis in various cancers, such as colorectal, colon, prostate, and pancreatic cancer. To find out whether 2-methoxy-4-vinyl phenol (2M4VP) inhibits HGFinduced metastasis, pancreatic cancer cells were first treated with 2M4VP for $30 \mathrm{~min}$ and then treated with HGF (10 $\mathrm{ng} / \mathrm{ml}$ ) for $30 \mathrm{~min}$. As expected, treatment of Panc-1 cells with HGF (10 $\mathrm{ng} / \mathrm{ml})$ resulted in about $40 \%$ increase in metastasis, but 2M4VP treatment inhibited the migration induced by HGF to levels of untreated cells (Figure 4A). In addition, we found that the levels of p-AKT increased with HGF treatment and decreased to untreated levels by pretreatment with 2M4VP (Figure 4B). These results suggest that $2 \mathrm{M} 4 \mathrm{VP}$ reduces the phosphorylation levels of HGFinduced AKT and inhibits metastasis of Panc-1 cells.

\section{Discussion}

2M4VP is an aromatic compound that has anti-inflammatory effects by inhibiting NO production and also inhibits cellcycle activation induced by the carcinogen benzopyrene ( 20 , 21). However, there are no studies on the specific effect of 

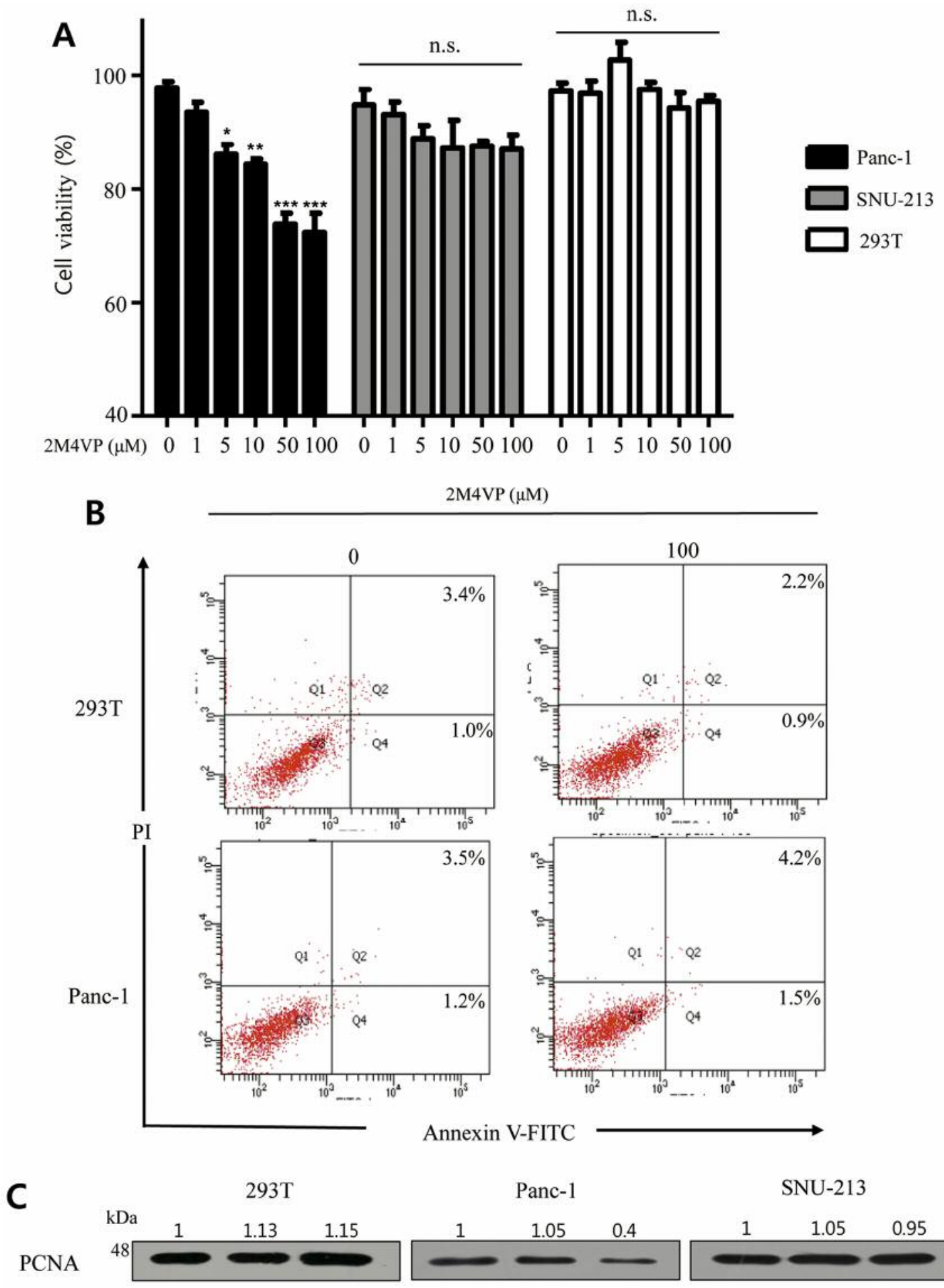

Annexin V-FITC

SNU-213
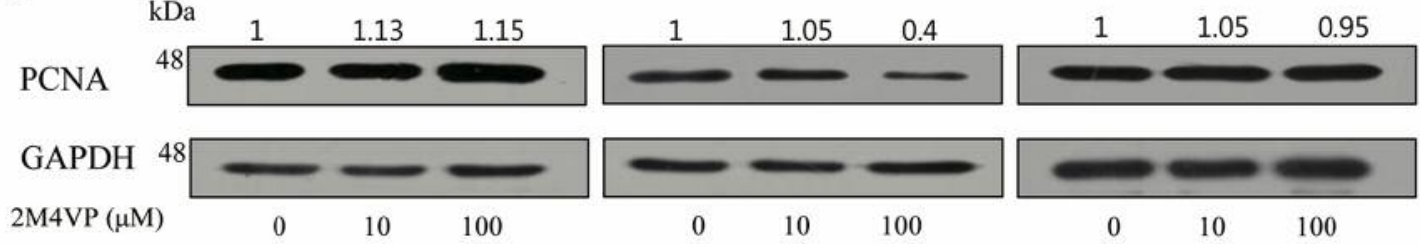

Figure 1. Effect of 2M4VP treatment on pancreatic cancer cell viability and expression of PCNA. (A) WST-1 assay performed after treatment of Panc-1, SNU-213, and 293T cells with 2M4VP $(0,5,10,50,100 \mu \mathrm{M})$. (B) Flow cytometry analysis of Panc-1 and $293 \mathrm{~T}$ cells after treatment with or without $2 \mathrm{M} 4 \mathrm{VP}$. (C) The expression of PCNA through western blot after treatment with $2 M 4 V P$ for $50 \mathrm{~h}$ in Panc-1, SNU-213, and $293 T$ cells. The relative band intensities of PCNA/GAPDH were measured using ImageJ software. ( $p<0.05$; stars indicate a significant difference vs. $\left.0, *_{p}<0.05, * * p<0.01, * * * p<0.001\right)$. 

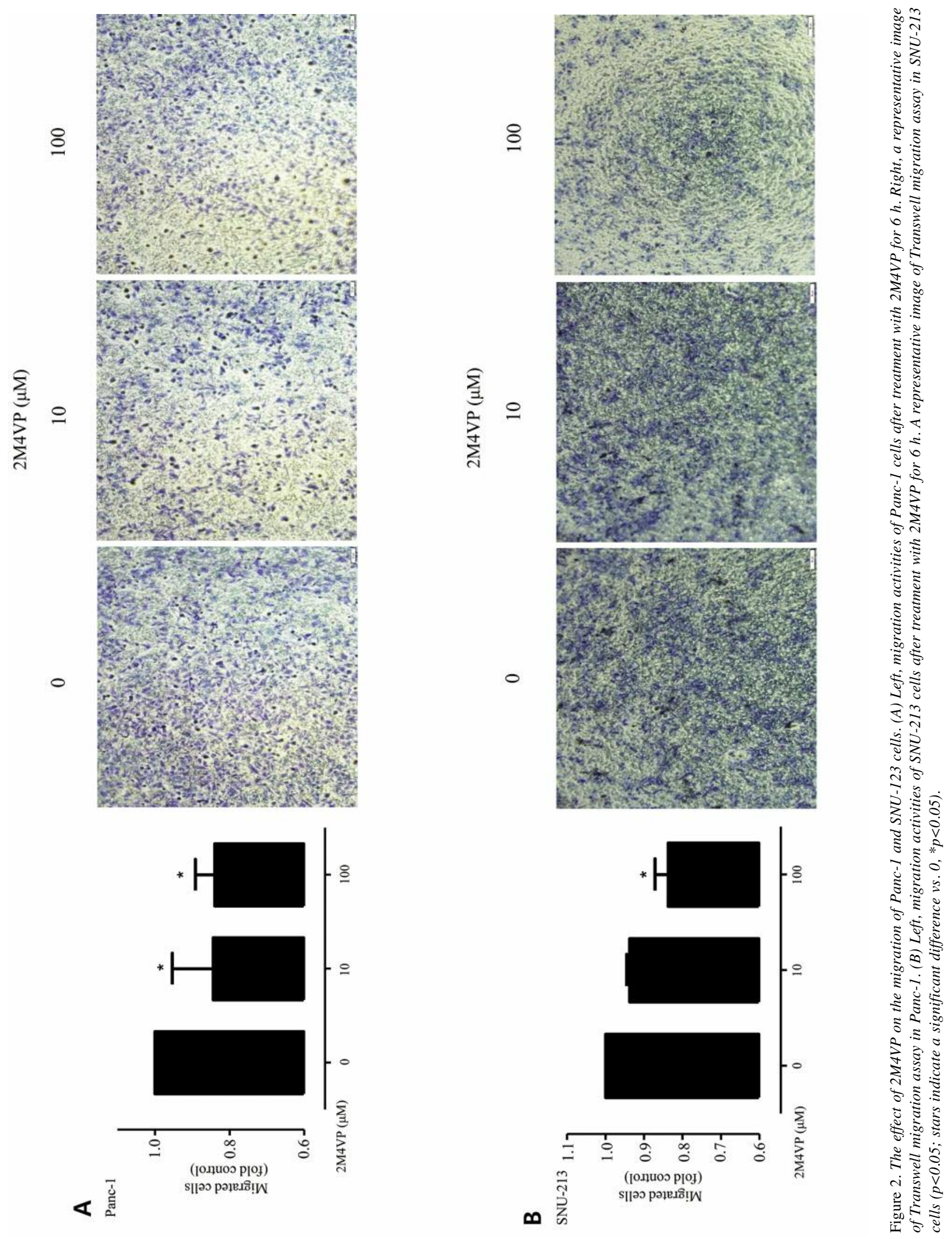


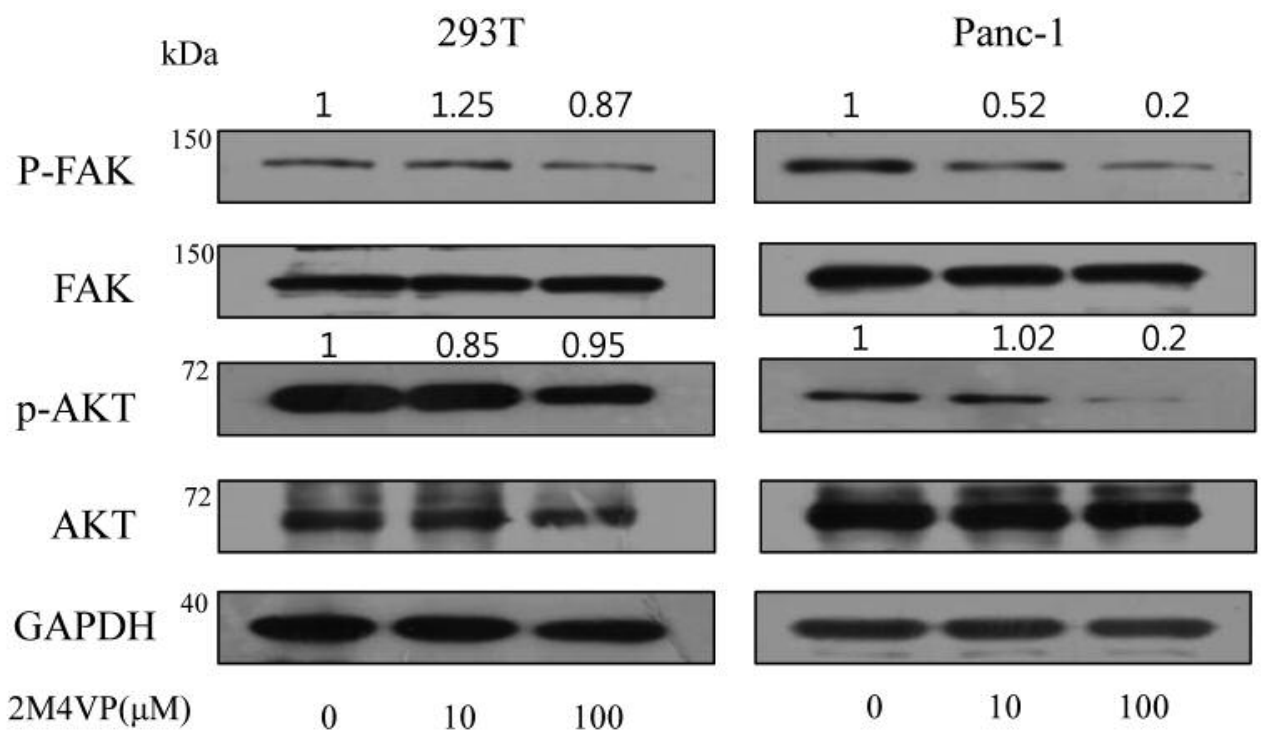

Figure 3. The expression and phosphorylation analysis of FAK and AKT in $293 T$ and Panc-1 cells. The relative band intensities of p-FAK/FAK and $p$-AKT/AKT were measured using ImageJ software.

2M4VP on cancer cells. In this study, we found that 2M4VP inhibited cell proliferation and metastasis in pancreatic cancer cells.

PCNA is known to regulate cell cycle and proliferation by tetramerization with cyclins and p21 (22). In this study, 2M4VP treatment reduced the expression of PCNA by more than $50 \%$ in Panc- 1 cells. Therefore, it can be suggested that 2M4VP inhibits Panc-1 cell proliferation by inhibiting PCNA expression. This result is similar to that of a previous report where matrine, a compound isolated from the legume, suppressed cell proliferation by inhibiting the expression of PCNA (23).

FAK is a non-receptor tyrosine kinase that activates downstream signaling pathways, such as proto oncogene tyrosine-protein kinase Src (Src) and phosphatidylinositol-3kinase (PI3K) /AKT (24). FAK has been reported to be overexpressed in malignant tumors and is known to play an important role in cell survival, proliferation, migration, and invasion (24-27). In previous studies, we have reported that flavonoids, such as quercetin and kaempferol, are effective in inhibiting pancreatic cancer metastasis by inhibiting FAK phosphorylation $(6,10)$. Similarly, 2M4VP inhibited metastasis through the FAK pathway, thereby reducing the phosphorylation levels of FAK.

Hepatocyte growth factor (HGF) and its receptor c-MET are of considerable interest because they are closely related to various human cancers. Many $\mathrm{HGF} / \mathrm{c}-\mathrm{MET}$ pathway inhibitors have been developed and evaluated in the clinic (28). These agents include MET antagonists, neutralizing antibodies against
HGF, and inhibitors of downstream signaling pathways. Phytochemicals including wihthaferin A and carnosol, block HGF/c-MET activation and attenuate migration in AsPC-1 pancreatic cancer cells, suggesting that phytochemicals are effective potential candidate therapeutics $(29,30)$. The $\mathrm{PI} 3 \mathrm{~K} / \mathrm{AKT}$ pathway is known to be activated when HGF binds to its receptor, and to control invasion and metastasis of cancer cells $(11,12)$. We found that HGF-induced cell migration in Panc-1 cells was reduced dose-dependently following treatment with 2M4VP. The induced AKT phosphorylation was also decreased. Since 2M4VP inhibits the translocation of NF-kB p65 into the nucleus (21), it is expected that 2M4VP regulates the $\mathrm{HGF} / \mathrm{FAK} / \mathrm{PI} 3 \mathrm{~K} / \mathrm{Akt} / \mathrm{NF}-\mathrm{kb}$ pathway in pancreatic cancer cells.

In conclusion, 2M4VP inhibited proliferation and metastasis in Panc-1 cells and blocked HGF-mediated metastasis. 2M4VP can be potentially used as an inhibitor of metastasis of pancreatic cancer cells.

\section{Conflicts of Interest}

The Authors have no conflicts of interest to declare regarding this study.

\section{Authors' Contributions}

DH Kim performed the experiments and drafted the main manuscript. SI Han, $\mathrm{UH} \mathrm{Oh}$, and $\mathrm{B}$ Go assisted with the experiments. DH Kim, CS Kim, and YH Jung analyzed and interpreted data. JH Kim and J Lee supervised the project. 
A

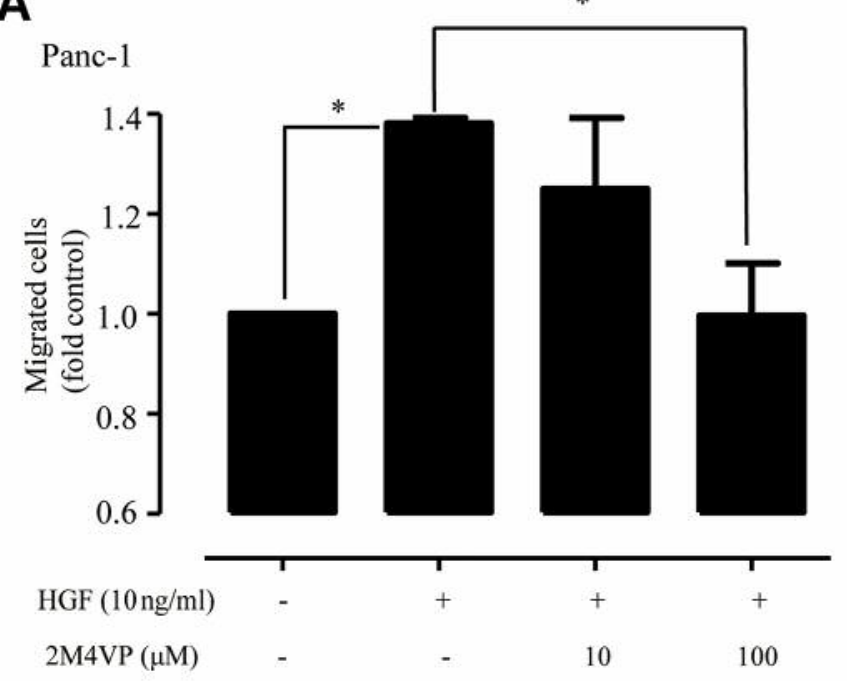

B

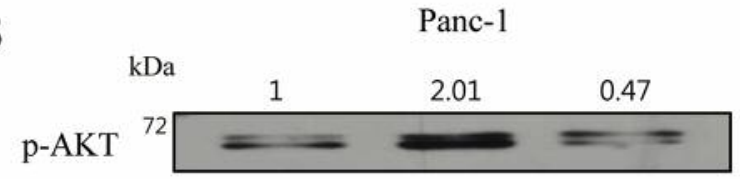

AKT

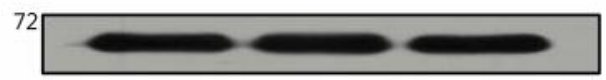

GAPDH

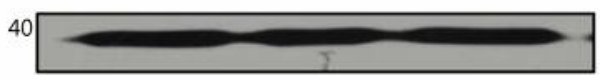

HGF

2M4VP

$(100 \mu \mathrm{M})$
$\operatorname{HGF}(10 \mathrm{ng} / \mathrm{ml})$
$2 \mathrm{M} 4 \mathrm{VP}(\mu \mathrm{M})$

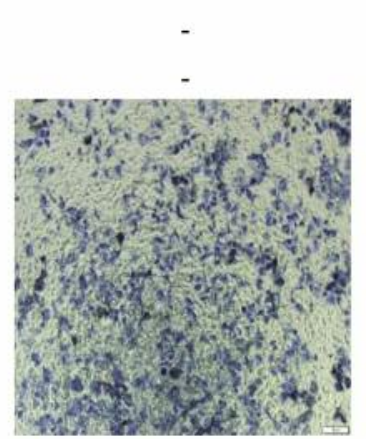

$+$

$-$

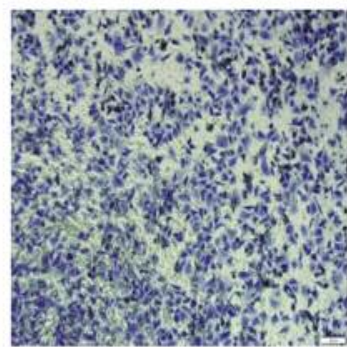

10

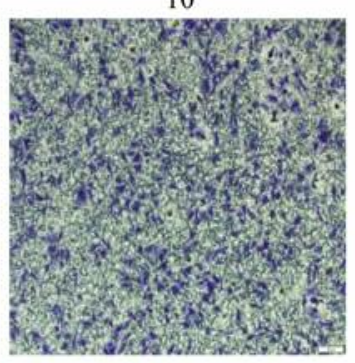

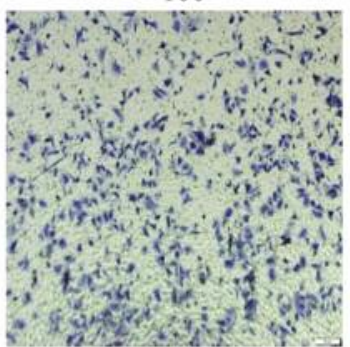

Figure 4. Inhibition of hepatocyte growth factor (HGF)-induced metastasis by 2M4VP and its effect on the expression and phosphorylation of AKT in Panc-1 cells. (A) Quantification of the effect of 2M4VP on HGF-induced migration in Panc-1 cells. Below, representative image of the Transwell migration assay in Panc-1 cells. (B) Effect of $2 M 4 V P$ on the expression and phosphorylation of AKT in HGF-treated Panc-1 cells. The relative band intensities of $p$-AKT/AKT were measured using ImageJ software $\left(p<0.05\right.$; stars indicate a significant difference $\left.v s .0,{ }^{*} p<0.05\right)$.

\section{Acknowledgements}

This work was supported by the Basic Science Research Program through the National Research Foundation of Korea (NRF) funded by the Ministry of Education (2016R1A6A1A03012862). This work was also supported by the Korean Institute of Planning and Evaluation for Technology in Food, Agriculture, Forestry and Fisheries (IPET) through the Agri-Bio Industry Technology Development Program, funded by Ministry of Agriculture, Food and Rural Affairs (MAFRA) (315027-4).

\section{References}

1 Neoptolemos JP, Dunn JA, Stocken DD, Almond J, Link K, Beger H, Bassi C, Falconi M, Pederzoli P, Dervenis C, Fernandez-Cruz L, Lacaine F, Pap A, Spooner D, Kerr DJ, Friess
H and Büchler MW; European Study Group for Pancreatic Cancer: Adjuvant chemoradiotherapy and chemotherapy in resectable pancreatic cancer: A randomised controlled trial. Lancet 358: 1576-1585, 2001. PMID: 11716884. DOI: 10.1016/ s0140-6736(01)06651-x

2 Smeenk HG, Van Eijck CHJ, Hop WC, Erdmann J, Tran KCK, Debois M, Van Cutsem E, Van Dekken H, Klinkenbijl JH and Jeekel J: Long-term survival and metastatic pattern of pancreatic and periampullary cancer after adjuvant chemoradiation or observation: Long-term results of EORTC trial 40891. Ann Surg 246: 734-740, 2007. PMID: 17968163. DOI: 10.1097/ SLA.0b013e318156eef3

3 Lee J, Lee J, Kim M and Kim JH: Dietary approach to attenuate human pancreatic cancer growth and migration with innoxiousness. J Funct Foods 30: 303-312, 2017. DOI: 10.1016/ j.jff.2016.12.032 
4 Keleg S, Büchler P, Ludwig R, Büchler MW and Friess H: Invasion and metastasis in pancreatic cancer. Mol Cancer 2: 17, 2003. PMID: 12605717. DOI: 10.1186/1476-4598-2-14

5 Dimagno EP, Reber HA and Tempero MA: AGA technical review on the epidemiology, diagnosis, and treatment of pancreatic ductal adenocarcinoma. Gastroenterology 117: 1464-1484, 1999. PMID: 10579989. DOI: 10.1016/s0016-5085(99)70298-2

6 Lee J and Kim JH: Kaempferol inhibits pancreatic cancer cell growth and migration through the blockade of EGFR-related pathway in vitro. PLoS One 11(5): e0155264, 2016. PMID: 27175782. DOI: 10.1371/journal.pone.0155264

7 Lee J, Lee J, Kim SJ and Kim JH: Quercetin-3-O-glucoside suppresses pancreatic cancer cell migration induced by tumordeteriorated growth factors in vitro. Oncol Rep 35: 2473-2479, 2016. PMID: 26820381. DOI: 10.3892/or.2016.4598

8 Bardeesy $\mathrm{N}$ and DePinho RA: Pancreatic cancer biology and genetics. Nat Rev Cancer 2: 897-909, 2002. PMID: 12459728. DOI: $10.1038 / \mathrm{nrc} 949$

9 Sugisawa N, Miyke K, Higuchi T, Oshiro H, Zhang Z, Park JH, Kawaguchi K, Chawla SP, Bouvet M, Singh SR, Unno M and Hoffman RM: Induction of metastasis by low-dose gemcitabine in a pancreatic cancer orthotopic mouse model: An opposite effect of chemotherapy. Anticancer Res 39(10): 5339-5344, 2019. PMID: 31570427. DOI: 10.21873/anticanres.13726

10 Ono H, Basson MD and Ito H: PTK6 Promotes cancer migration and invasion in pancreatic cancer cells dependent on ERK signaling. PLoS One 9(5): e96060, 2014. PMID: 24788754. DOI: 10.1371/journal.pone.0096060

11 Lee J, Han S, Yun J and Kim JH: Quercetin 3-O-glucoside suppresses epidermal growth factor - induced migration by inhibiting EGFR signaling in pancreatic cancer cells. Tumour Biol 36(12): 9385-9393, 2015. PMID: 26109002. DOI: 10.1007/s13277-015-3682-x

12 Pothula SP, Xu Z, Goldstein D, Biankin AV, Pirola RC, Wilson JS and Apte MV: Hepatocyte growth factor inhibition: A novel therapeutic approach in pancreatic cancer. Br J Cancer 114: 269280, 2016. PMID: 26766740. DOI: 10.1038/bjc.2015.478

13 Watanabe S, Kishimoto T and Yokosuka O: Hepatocyte growth factor inhibits anoikis of pancreatic carcinoma cells through phosphatidylinositol 3-kinase pathway. Pancreas 40: 608-614 2011. PMID: 21499215. DOI: 10.1097/MPA.0b013e31 $8214 \mathrm{fa} 6 \mathrm{c}$

14 Zhou W, Jubb AM, Lyle K, Xiao Q, Ong CC, Desai R, Fu L, Gnad F, Song Q, Haverty PM, Aust D, Grützmann R, Romero M, Totpal K, Neve RM, Yan Y, Forrest WF, Wang Y, Raja R, Pilarsky C, De Jesus-Acosta A, Belvin M, Friedman LS, Merchant M, Jaffee EM, Zheng L, Koeppen H and Hoeflich KP: PAK1 mediates pancreatic cancer cell migration and resistance to MET inhibition. J Pathol 234: 502-513, 2014. PMID: 25074413. DOI: $10.1002 /$ path.4412

15 Bai CZHI, Feng MALI, Hao XUL and Zhao ZHIJ: Anti-tumoral effects of a trypsin inhibitor derived from buckwheat in vitro and in vivo. Mol Med Rep 12: 1777-1782, 2015. PMID: 25901645. DOI: $10.3892 / \mathrm{mmr} .2015 .3649$

16 Janeš D, Kantar D, Kreft S and Prosen H: Identification of buckwheat (Fagopyrum esculentum Moench) aroma compounds with GC - MS. Food Chem 112: 120-124, 2009. DOI: 10.1016/j.2008.05.048

17 Sun T and Ho C: Antioxidant activities of buckwheat extracts. Food Chem 90: 743-749, 2005. DOI: 10.1016/j.2004.04.035
18 Shii SI, Atsumura TK, Hiozuka CS, Oyauchi KO, Awasaki KK, Akigawa ST, Ukushima TF, Okuji YT, Inoshita MK, Hnishi MO, Awahara MK and Hba KO: Anti-inflammatory effect of buckwheat sprouts in lipopolysaccharide-activated human colon cancer cells and mice. Biosci Biotechnol Biochem 72: 31483157, 2008. PMID: 19060399. DOI: 10.1271/bbb.80324

19 Al-snafi PAE and Medicine C: A review on Fagopyrum esculentum: A potential medicinal plant. IOSR J Pharm 7: 2132, 2017. PMID: 27104519 . DOI: 10.3390/ijms17040589

20 Jeong JB and Jeong HJ: 2-Methoxy-4-vinylphenol can induce cell cycle arrest by blocking the hyper-phosphorylation of retinoblastoma protein in benzo[a]pyrene-treated NIH3T3 cells. Biochem Biophys Res Commun 400: 752-757, 2010. PMID: 20816752. DOI: $10.1016 /$ j.bbrc.2010.08.142

21 Jeong JB, Hong SC, Jeong HJ and Koo JS: Anti-inflammatory effect of 2-methoxy-4-vinylphenol via the suppression of NF-kB and MAPK activation, and acetylation of histone H3. Arch Pharm Res 34: 2109-2116, 2011. PMID: 22210037. DOI: 10.1007/s12272-011-1214-9

22 Wei $\mathrm{H}$, Wang $\mathrm{C}$ and Chen L: Proliferating cell nuclear antigen, survivin, and CD34 expressions in pancreatic cancer and their correlation with hypoxia-inducible factor $1 \alpha$. Pancreas 32: 159-163, 2006. PMID: 16552335. DOI: 10.1097/01.mpa.0000202961. $71600.9 \mathrm{~b}$

$23 \mathrm{Lu} \mathrm{Z}$, Xiao Y, Liu X, Zhang Z, Xiao F and Bi Y: Matrine reduces the proliferation of A549 cells via the p53/p21/ PCNA/eIF4E signaling pathway. Mol Med Rep 15: 2415-2422, 2017. PMID: 28447756. DOI: $10.3892 / \mathrm{mmr} .2017 .6331$

24 Kanteti R, Mirzapoiazova T, Riehm JJ, Dhanasingh I, Mambetsariev B, Wang J, Kulkarni P, Kaushik G, Seshacharyulu P, Ponnusamy MP, Kindler HL, Nasser MW, Batra SK and Salgia R: Focal adhesion kinase a potential therapeutic target for pancreatic cancer and malignant pleural mesothelioma. Cancer Biol Ther 19: 316-327, 2018. PMID: 29303405. DOI: 10.1080/15384047.2017.1416937

25 Peng X and Guan JL: Focal Adhesion Kinase: From in vitro studies to functional analyses in vivo. Curr Protein Pept Sci 999: 1-16, 2011. PMID: 21190526.

26 Mitra SK, Hanson DA and Schlaepfer DD: Focal adhesion kinase: In command and control of cell motility. Nat Rev Mol Cell Biol 6: 56-68, 2005. PMID: 15688067. DOI: 10.1038/nrm1549

27 Schaller MD: Cellular functions of FAK kinases: insight into molecular mechanisms and novel functions. J Cell Sci 123(Pt 7): 1007-1013, 2010. PMID: 20332118. DOI: $10.1242 /$ jcs.045112

28 Liu X, Newton RC and Scherle PA: Developing c-MET pathway inhibitors for cancer theapy: progress and challenges. Trends Mol MEd 16: 37-45, 2010. PMID: 20031486. DOI: 10.1016/j.molmed. 2009.11.005

29 Aliebrahimi S, Kouhsari SM, Arab SS, Shadboorestan A and Ostad SN: Phytochemicals, withaferin A and carnosol, overcome pancreatic cancer stem cells as c-Met inhibitors. Biomed Phamacothe 106: 1527-1536, 2018. PMID: 30119228. DOI: 10.1016/j.biopha.2018.07.055

30 Singh S, Sharma B, Kanwar SS and Kumar A: Lead phytochemicals for anticancer drug development. Front Plant Sci 7: 1-13, 2016. PMID: 27877185. DOI: 10.3389/fpls.2016.01667

Received September 24, 2019

Revised November 18, 2019

Accepted November 18, 2019 